\title{
The SMART model: Soft Membranes Adapt and Respond, also Transiently, in the presence of antimicrobial peptides ${ }^{\dagger}$
}

\author{
Burkhard Bechinger*
}

\begin{abstract}
Biophysical and structural studies of peptide-lipid interactions, peptide topology and dynamics have changed our view on how antimicrobial peptides insert and interact with membranes. Clearly, both the peptides and the lipids are highly dynamic, change and mutually adapt their conformation, membrane penetration and detailed morphology on a local and a global level. As a consequence, the peptides and lipids can form a wide variety of supramolecular assemblies in which the more hydrophobic sequences preferentially, but not exclusively, adopt transmembrane alignments and have the potential to form oligomeric structures similar to those suggested by the transmembrane helical bundle model. In contrast, charged amphipathic sequences tend to stay intercalated at the membrane interface where they cause pronounced disruptions of the phospholipid fatty acyl packing. At increasing local or global concentrations, the peptides result in transient membrane openings, rupture and ultimately lysis. Depending on peptide-to-lipid ratio, lipid composition and environmental factors (temperature, buffer composition, ionic strength, etc.), the same peptide sequence can result in a variety of those responses. Therefore, the SMART model has been introduced to cover the full range of possibilities. With such a view in mind, novel antimicrobial compounds have been designed from amphipathic polymers, peptide mimetics, combinations of ultra-short polypeptides with hydrophobic anchors or small designer molecules. Copyright @ 2014 European Peptide Society and John Wiley \& Sons, Ltd.
\end{abstract}

Keywords: magainin; alamethicin; membrane topology; local disorder; membrane pore; membrane macroscopic phase; carpet model; toroidal pore; hydrophobic mismatch; cecropin; peptide-lipid interactions; PGLa; peptaibol; equlibria

\section{Introduction}

Q1 In view of a worldwide re-emergence of infectious diseases and a rapid increase in pathogens that are multi-resistant to commercially available antibiotics, new strategies to fight such infections have to be developed. When bacteria become resistant, more costly second-line antibiotics are used, but even these drugs become ineffective over time [1]. As a consequence, the development of novel antibiotics is needed to counteract the steady decline of approved pharmaceuticals where alternative agents with completely novel mechanisms of action are desirable. A promising strategy is based on copying the mechanism of action of natural compounds such as antimicrobial peptides (AMPs). These effector molecules of innate immunity provide a first line of defence against a multitude of pathogenic microorganisms and are capable to keep in check many invaders of higher organisms [2,3]. They work, e.g., by physical interference with the barrier function of bacterial membranes, and there is good evidence that the latter are indeed the primary target of a large number of AMPs. Notably, when compared with antibiotics that interact with specific receptors, bacteria are less likely to develop resistance to AMPs interfering with the lipid bilayer [4].

Therefore, naturally occurring AMPs are valuable template structures to develop new concepts for efficient pharmaceutical compounds with increased efficiency. Indeed, recent research efforts following this strategy have come up with small amphipathic molecules, pseudopeptides and even polymers that all exhibit potent antimicrobial activities (e.g. [5-9]). In order to achieve this goal, a number of membrane-active peptides, many available from natural sources, some by design, have been studied by biophysical and biochemical methods. These peptides included early on alamethicin and melittin [10], and later magainins [11], cecropins and designed peptides [12-14] (cf Table 1 for sequence informa- T1 tion). By combining the insights from a variety of biophysical studies on different sequences, a comprehensive view on polypeptide lipid interactions and the mechanisms of membrane permeabilization and pore formation have been obtained. Up to this day, unexpected structural and dynamic features of membraneassociated polypeptides are discovered $[15,16]$, and a picture emerges with multiple equilibria that govern their membrane interactions and conformations (Figure 1).

Here, some of the biophysical data from a selected set of peptides will be reviewed, which consolidate in a view of how the peptides interact with membranes in a highly dynamic manner.

\footnotetext{
* Correspondence to: Burkhard Bechinger, Faculté de chimie, Institut le Bel, 4, rue Blaise Pascal, 67070 Strasbourg, France. E-mail: bechinge@unistra.fr

Contribution to the Special Issue dedicated to the Naples Workshop on Antimicrobial Peptides 2014
}

Université de Strasbourg/CNRS, UMR7177, Institut de Chimie, 4, rue Blaise Pascal, 67070 Strasbourg, France

Abbreviations: Aib, $\alpha$-aminobutyric acid; AMP, antimicrobial peptide; DMPC, 1,2dimyristoyl-sn-glycero-3-phosphocholine; DMPG， 1,2-dimyristoyl-sn-glycero-3phospho-(1'-rac-glycerol); DOPC, 1,2-dioleoyl-sn-glycero-3-phosphocholine; DOPG, 1,2-dioleoyl-sn-glycero-3-phospho-(1'-rac-glycerol); GUV, giant unilamellar vesicle; $I P$, in-plane; LUV, large unilamellar vesicle; NMR, nuclear magnetic resonance; $P C$, phosphatidylcholine; $P E$, phosphatidylethanolamine; $P G$, phosphatidylglycerol; PS, phosphatidylserine; POPC, 1-palmitoyl-2-oleoyl-sn-glycero-3-phosphocholine; $T M$, transmembrane. 


\section{Biography}

Burkhard Bechinger obtained his PhD in 1989 in the Department of Biophysical Chemistry at the Biocenter of the University of Basel in Switzerland on the study of electrostatic interactions within lipid bilayers. Thereafter, he became postdoctoral research associate at the University of Pennsylvania (1990-1993) where he developed solid-state NMR spectroscopy for the investigation of membrane-associated

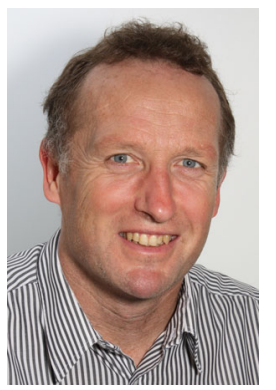
polypeptides. As a result of this work, it was discovered for the first time that cationic amphipathic peptides orient parallel to the membrane surface. He started his own research group in 1993 at the Max Planck Institute of molecular Physiology, Dortmund Germany and as the head of an Independent Junior Research Group at the MPI of Biochemistry in Martinsried, Germany (1995-2001). During this time period, he and his team investigated histidine-containing flipper peptides that change membrane topology as a function of $\mathrm{pH}$ and have potent antimicrobial and nucleic acid transfection properties. Since 2001, he is a full professor at the chemistry department of the University of Strasbourg, France where his team designs and studies peptides with different biological activities as well as membrane proteins using NMR spectroscopy and a variety of other biophysical approaches.

Not only the conformation of the polypeptide chains undergoes profound changes but also the lipid bilayers adapt and respond to the insertion of peptides into their hydrophobic core and/or interface. The examples that will be discussed include the very hydrophobic peptaibols from fungi and some of the much more amphipathic cationic sequences that are frequently found in amphibians. Whereas the schemes presented in Figure 1 provide a common description of their membrane interactions, the very details and their preferred topology and aggregation state is dictated by the physicochemical properties of the peptides and the lipids under investigation. In the following, biophysical investigations on hydrophobic peptaibol sequences and amphipathic linear cationic AMPs shall be reviewed before a model will be presented unifying different sequences and experimental conditions. The paper starts by presenting data on the hydrophobic peptides such as alamethicins, which served for a long time as the paradigm for peptide-membrane interactions and formed our 'classical view' on how proteins and peptides interact with lipid membranes.

\section{Hydrophobic Sequences with a Strong Pro- pensity for Transmembrane Alignments: Alamethicin as an Example}

Alamethicin is composed of 20 residues and the best-investigated member of the peptaibol family, peptides of fungal origin that encompass $\alpha$-aminobutyric acid (Aib) residues at high abundance [17] (Table 1). In the presence of alamethicin and other peptaibols, voltage-dependent conductance changes have been measured with well-defined ohmic resistance, opening times and frequency [18-22]. Therefore, at a time when the structures of membrane proteins were largely unknown, alamethicins served as a paradigm for large voltage- or ligand-gated channel proteins (reviewed, e.g., in [23]). The alamethicin pore has been modelled as a 'transmembrane helical bundle' in which the individual helices are grouped with their more hydrophilic side facing the water-filled pore. The measured conductivities of the water filled openings created in this manner agree reasonably well with theoretical predictions where the smallest conducting oligomers are made of three, four or five subunits (reviewed in $[10,23]$ ). The higher conductance states have been explained by the assembly of increased order oligomers. Therefore, it has been suggested that the peptides follow a series of equilibria where they transfer from the aqueous environment to an interface-associated -, a membrane inserted state and the for- Q2 mation of oligomers [20,24-27] (Figure 1(A)).

Whereas the initial formation and the decay of the lowest conductance state are characterized by high activation energies (50 and $120 \mathrm{~kJ} / \mathrm{mol}$, respectively), further addition and subtraction of subunits occur quickly on a millisecond time scale. More recently, molecular dynamics calculations of membrane-bound alamethicin suggest that the macromolecular arrangement of the helix bundle is less regular and more asymmetric than the first pictural views suggested [28].

Indeed, oriented solid-state NMR spectroscopy shows a strong propensity of alamethicins for transmembrane (TM) alignments in DMPC and POPC membranes [29-31]. This is consolidated by solution-state NMR experiments where a preference for helical

Table 1. Sequences of peptides discussed in this paper

mellttin

Magainin 2

PGLa

cecropin A

PMAP-23

LAH4

Alamethicin (F50/7)

Ampullosporin A

Antiamoebin

Trichonin GA IV

Zervamicin IIB

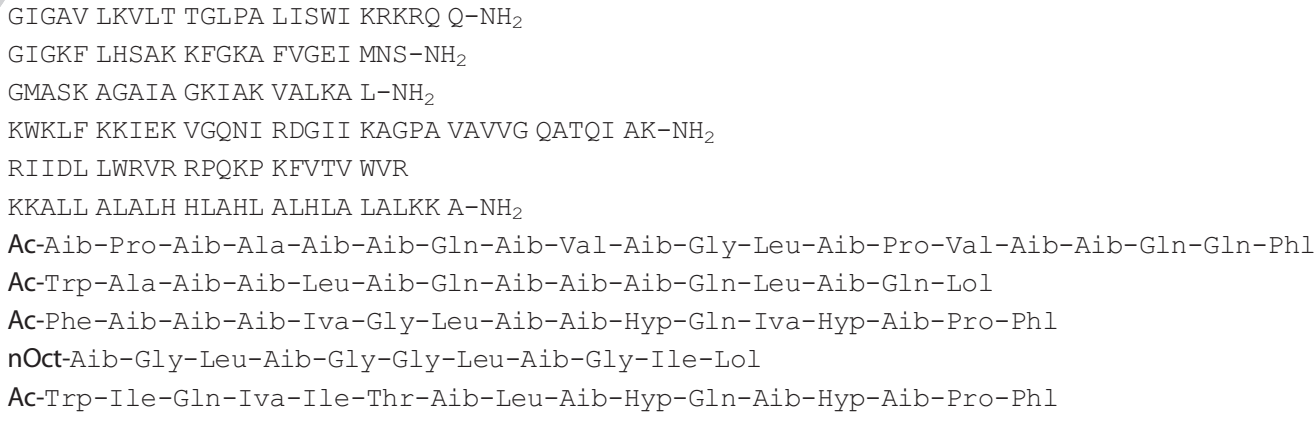

The one-letter code is used for peptides made from conventional amino acids only. The peptaibols sequences are given by the three-letter code with the following non-standard residues: Aib, a-aminoisobutyric acid; Iva, D-isovaline; Hyp, trans-4-hydroxy-L-proline; Phl, L-phenylalaninol; Lol, L-leucinol; Ac-, acetyl-; $n$-Oct, $n$-octanyl; $\mathrm{NH}_{2}$, the carboxyamide termini. 


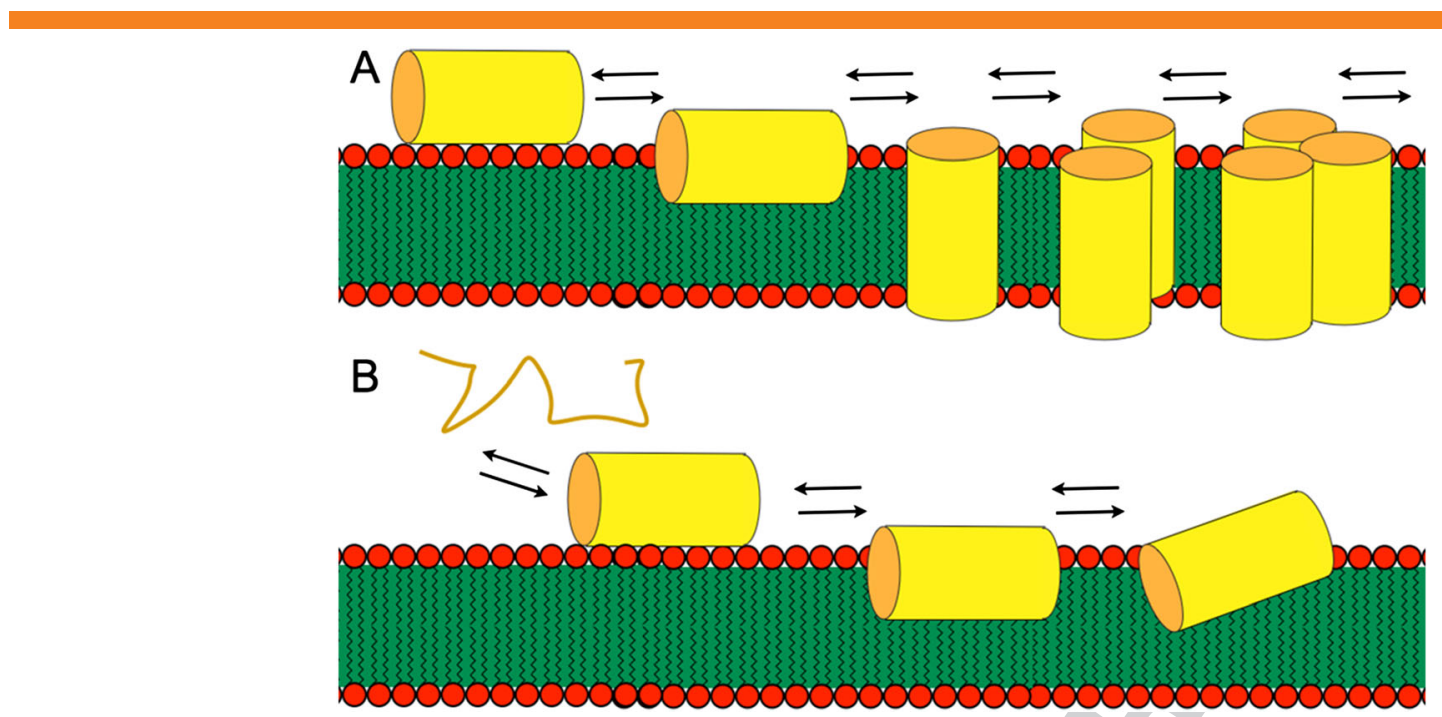

Figure 1. Schematic diagram showing the equilibria governing membrane insertion and interactions of (A) hydrophobic sequences such as alamethicin and (B) charged amphipathic peptides with a high hydrophobic moment such as magainins.

conformations with a flexible hinge region around proline-14 has been observed [32,33].

A more detailed analysis reveals a quite dynamic picture where the peptides exhibit a high degree of conformational flexibility and structural details that are a function of the physical state of the lipid, the lipid-peptide ratio, the presence of TM potentials and other factors (reviewed, e.g., in $[10,23])$. It has even been possible to define peptide-to-lipid ratios and membrane lipid compositions, including the ones close to that of bacterial membranes, where the alamethicin helices predominantly align parallel to the membrane surface $[16,34]$. Finally, related arrangements of TM helices have been revealed for many membrane proteins including potassium channels, the acetylcholine receptor, the Influenza proton channel or the phospholamban pentamer [35-37].

It is thought that alamethicin initially adsorbs and intercalates to the membrane interface, a configuration which is gated into a series of subsequent equilibria (Figure 1(A)), where the realignment of the helix dipole by TM electric fields can help in the insertion process (reviewed in [10,23]). TM orientations have been observed for other hydrophobic polypeptide sequences [14,36,38-40], including the membrane anchors of colicins [41] or Bcl-xL [42]. Interestingly, the membrane topology of the latter is controlled by a sensitive equilibrium between in-plane and TM configurations, which may be important to allow for the reversible association of these proteins, which are of about $20 \mathrm{kDa}$ in size.

Interesting insight into the interaction contributions that determine the membrane alignment of hydrophobic membrane sequences is obtained when closely related peptaibols that carry fewer residues than alamethicin are investigated. Indeed, shorter peptaibols (e.g. Table 1) still exhibit single channel conductances that resemble that of the longer sequence. When studied in more detail, zervamcin Ila (16 residues) tends to form relatively large oligomeric assemblies from which the exchange of monomers occurs at an order of magnitude increased rate when compared with alamethicin [21]. In a related manner, alamethicin causes rather high conductance levels when reconstituted into thick membranes [43]. Indeed, under conditions of hydrophobic mismatch, considerable membrane deformations occur $[14,44,45]$, which can probably be alleviated by assembly of the peptides into larger structures. In contrast, antiamoebin (16 residues) does not exhibit single-channel conductivities under conditions where other peptaibols produce such conductivities [22]. In a similar manner, the pore-forming activities of trichogin GA IV (11 residues extended by $n$-octanoyl) are much reduced in membranes of average thickness but can be restored in thinner membranes [45].

Interestingly, when investigated by solid-state NMR, zervamicin Ila (16 residues) and ampullosporin A (15 residues; Table 1) are found to predominantly orient parallel to the surface of POPC membranes $[31,46]$. When reducing the membrane thickness by reconstituting the peptides into $P C$ bilayers made from $C 10: 0$ or C12:0 fatty acyl chains, these shorter peptaibols insert into a TM configuration indicating that hydrophobic mismatch energies become an important contribution to membrane topology. In the thicker membranes, the short peptides impose strain onto the membrane and disrupt the regular lipid packing shifting the equilibrium to the in-planar states (Figure 1(A)). Whereas favourable energy contributions for TM insertion arise by moving hydrophobic residues from the membrane interface or from the aqueous phase into the region of the hydrocarbon chains, unfavourable interactions are associated with such lipid-derived energy contributions. Even though these and other energy contributions have been discussed previously, including the removal of charges from side chains, oligomerization or polar interactions within the hydrophobic environment (e.g. reviewed in [47]), it should be noted that overall large favourable and large unfavourable energy contributions are involved in the insertion process, which makes the prediction of the membrane topology rather difficult. This may also explain why anticipating the membrane topology by molecular dynamics simulations remains a difficult task, and the comparison with experimental data remains essential to validate such calculations [48-51].

This short summary of a wealth of biophysical investigations on peptaibols reveals that even for these peptides that are considered paradigms for TM helical bundle formation, the situation is much more complex than was initially expected. Notably, these seemingly 'well-understood' sequences can deviate from the classical view of a stable TM helical bundles. Therefore, it is not surprising that the situation becomes even more complex when cationic amphipathic peptides are considered where additional electrostatic interactions and upon membrane insertion profound changes in the peptide physicochemical properties along the polar/apolar interface occur. 


\section{The Membrane Interactions of Strongly Cationic Amphipathic AMPs}

Magainins and cecropins were among the first sequences that founded the family of linear cationic amphipathic sequences $[3,52]$ (Table 1). Peptides of this class have meanwhile been identified in many species where they establish an efficient and highly reactive defence mechanisms against a wide variety of infections $[3,52]$. A number of observations point to a direct interaction of these peptides with phospholipid membranes of bacteria and fungi where they often disrupt the bilayer integrity. These peptides inhibit the growth of sensitive microorganisms, exhibit cell killing activities and/or enter into the cell interior [53]. In addition, they have been found to modulate the immune response of the host organisms. To take into account their extended functionality, the term 'host defence peptides' has been introduced [54-56].

When the linear cationic AMPs are considered, magainins and its derivatives are probably the ones whose membrane interactions have been investigated most extensively using a wide variety of biophysical experiments (e.g. [57-61]). Upon addition to preformed bilayers, magainins and cecropins have been found to often lyse the membranes. However, in some experiments, discrete multilevel conductances are also observed [62-64]. Unlike the alamethicin channels, those recorded in the presence of magainins or cecropins are less well defined, erratic and characterized by large variations.

Interesting insights into the membrane interactions of magainin 2 have also been obtained when the kinetics of pore formation and the size of the openings have been investigated by fluorophore release experiments using giant unilamellar vesicles (GUVs). These vesicles are large enough (typically several micrometres) such that it is possible to follow single events and by repeating the experiment many times analyse theses in a statistical manner [65]. After addition of magainin, it takes one or a few minute before the release of fluorophore sets in, which then empties the vesicle within about $30 \mathrm{~s}$ [65]. These data indicate that the rate-limiting step is pore formation rather than the membrane permeation through a pore and in agreement with an all-or-none mechanism that has been obtained when analysing calcein release from LUV suspensions [66]. Pores form when the ratio of membrane-associated magainin 2 over lipid reaches about $0.7 \mathrm{~mol} \%$ in DOPC/DOPG GUVs, with only a small dependence on the DOPC/DOPG ratio [67]. Membrane openings occur in two stages, starting with an initial rapid release of fluorophore where very large pores form transiently. These have been associated with the unbalance in tension between the outer and inner monolayers when magainin associates with the outside of the GUV. Once the membrane ruptures and lipids and magainin re-equilibrate between the two bilayer leaflets, smaller pores form, thus slowing down the leakage of the fluorophore [68]. When the size of these openings is tested, even the persistent pores are found to be quite large with a cut-off of the hydrodynamic radius for the exiting molecules in the $3 \mathrm{~nm}$ range (corresponding to proteins of $\mathrm{MW}>20 \mathrm{kDa}$ ) [68].

Magainins and cecropins are about 20-40 residues in length, highly charged (Table 1) and, therefore, soluble in aqueous solution where they exhibit a high degree of random coil conformations [69]. When associating with the membrane, helical conformations are induced (Figure 2), a process that provides about half the Gibbs F2 free energy of membrane association (about $-0.8 \mathrm{kcal} / \mathrm{mol}$ per residue undergoing the transition $[74,75])$. Solid-state NMR and oriented $C D$ spectroscopies indicate that they reversibly associate with the membranes with the helix axis oriented parallel to the membrane surface [11]. This alignment of magainins [58,76,77], their analogues [78-80] and of a considerable number of other linear cationic AMPs [81-85] contrasts that of the much more hydrophobic alamethicin. However, an interfacial alignment is in agreement with the large hydrophobic moment obtained when these charged amphipathic sequences adopt helical conformations (Figure 2). Indeed, molecular modelling calculations visualize how magainin 2 and the designer peptide LAH4 (Table 1) could cause the formation of membrane lipidic pores without the need to adopt a well-defined assembly of TM domains or of peptide-peptide contacts $[50,86,87]$. This behaviour can be rationalized by the molecular shapes of lipids and the peptide $[88,89]$. When inserted into the membrane, one would expect that the charged residues reside in the membrane interface, whereas the hydrophobic side chains localize below the lipid carbonyls (Figure 3).

Whereas the topology of magainin 2 parallel to the membrane surface appears stable in solid-state NMR and fluorescence experiments and has been reproduced in a wide variety of lipid bilayers $[11,58]$, the close relative PGLa changes its tilt angle when reconstituted in di-saturated membranes at higher peptide-to-lipid ratio (Figure $1(\mathrm{~B})$ ). The change in tilt by about $30^{\circ}$ has been rationalized by homodimer formation [90], but this hypothesis still needs to be proven experimentally [91]. The tendency of PGLa to insert into PC or PC/PG membrane made of di-saturated fatty acyl chains is further enhanced in thin membranes or in the presence of magainin 2 [92,93]. However, in bilayers made of palmitoyl-oleoylphospholipids, which are thought to better represent the thickness and fatty acyl composition of natural membranes, stable in-planar alignments are also obtained for PGLa even in the presence of magainin $2[11,92,94]$ (cf below).

The association of magainin 2 is characterized by a partitioning coefficient in the $1000 \mathrm{M}^{-1}$ range, but the apparent partitioning

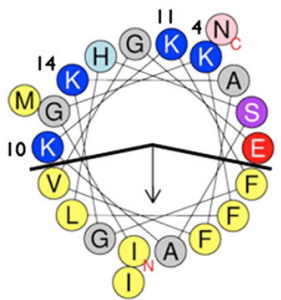

mag 2-22

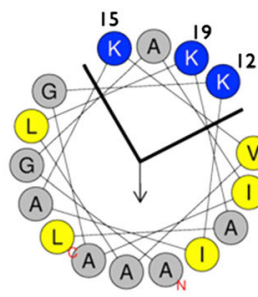

PGLa 6-21

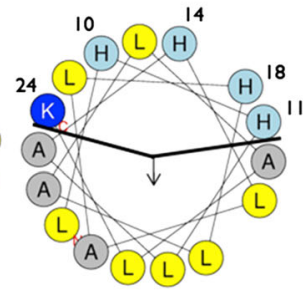

LAH4 9-24

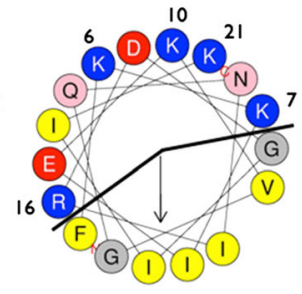

$\operatorname{cec} A$ 5-21

Figure 2. Helical wheel analysis and hydrophobic moment calculations of the amphipathic helical domains of magainin 2, PGLa, LAH4 and cecropin A using the Heliquest program [70]. The structures were obtained in DPC micelles [57,71,72] or for cecropin A in 15\% hexafluoro isopropanol [73]. For LAH4, the structural data obtained at pH 4.1 were used. The hydrophobic moments were $0.52,0.38,0.46$ and 0.59 , respectively. In the case of LAH4, this value was obtained when virtually replacing the histidines by lysines, in order to mimic histidines in its charged state at the low pH of the experiment. 

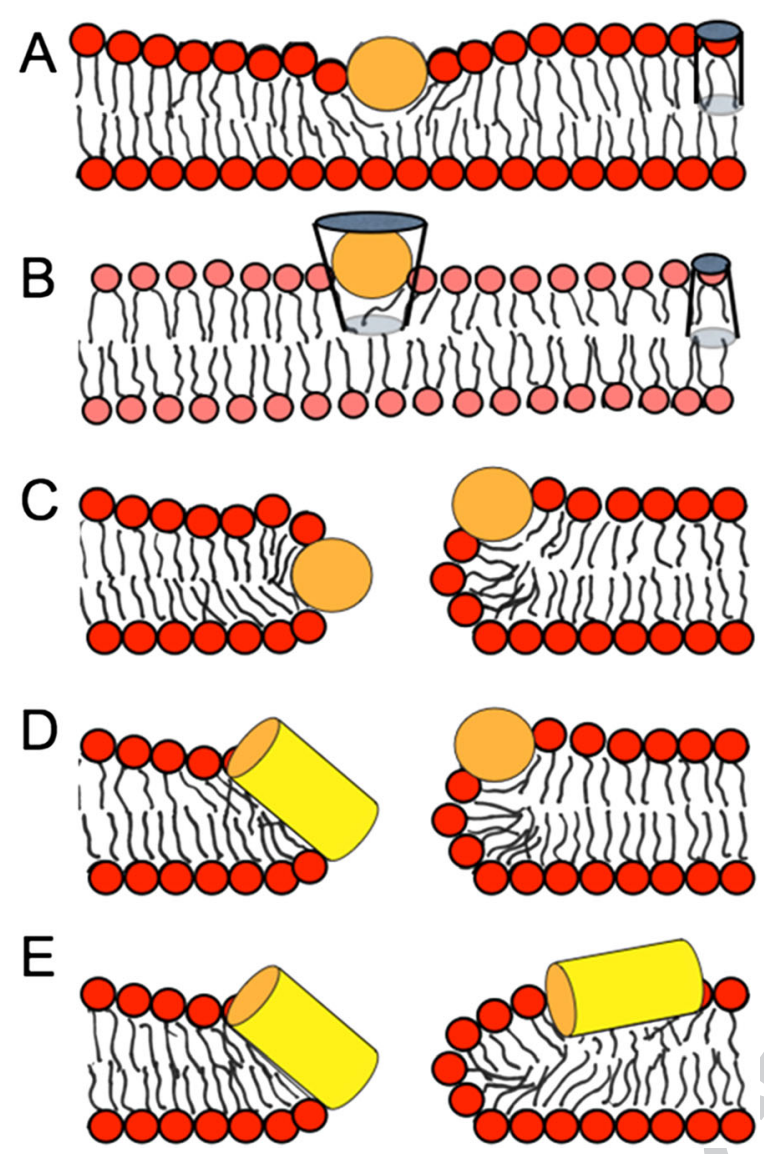

Figure 3. The effects an in-plane oriented peptide (coloured yellow and ochre) has on the bilayer packing. (A) An isolated amphipathic helix (seen along the helix axis) in a PC membrane. (B) The smaller head group of PE lipids partially compensate for the membrane-disruptive effects of the helix. (C, D and E) Higher local concentrations of peptides cause the transient opening of the membrane. During such events, the peptide can diffuse from one side to the other without changing the alignment relative to the membrane normal $(\mathrm{C})$ or by transiently adopting a different orientation (D, E). The cylindrical shape of PC lipids is sketched in panel $A$, the cone shape of PE and the inverted cone shape of the membraneinserted amphipathic helix, respectively, in panel B.

constant is increased by two to three orders of magnitude in the presence of acidic phospholipids $[95,96]$. This is due to the accumulation of positively charged ions and macromolecules next to the negatively charged surface. In this manner, the binding equilibrium appears increased, but when the much higher local concentration next to the surface, rather than the peptide concentration in bulk solution, is taken into account, very similar partitioning coefficients are obtained [96]. Therefore, negatively charged lipopolysaccharides and anionic lipids at the outer surface of bacterial cells enhance the local concentrations in the proximity of the membrane and are probably an important determinant for the selectivity of the peptides for bacterial over eukaryotic cells. This 'electrostatic response' also explains why tumour cells, where the PS content of the outer monolayer is increased, are more susceptible to the action of these peptides when compared with healthy cells [96-100]. Within the same concept, the changes in the electrostatic potential during the association of cationic peptides and the concomitant release of peripheral membrane proteins have been suggested to be a determinant of antimicrobial activities [101].

It seems that the membrane penetration depth and topology are also modulated by the presence of negatively charged lipids [102] and that segregation of domains enriched in cationic peptide and acidic phospholipids occurs $[103,104]$. Recently, it has also been demonstrated that the antimicrobial designer peptide LAH4 (Table 1) and other amphipathic sequences distribute unevenly in mixed PC/PS membranes probably by adopting a mesophase-like arrangement on the membrane surface [105]. This phenomenon is still under investigation, but the resulting increase in concentration and organization could have important implications for the mechanism of action and the selectivity of AMPs.

When the highly cationic amphipathic peptides adopt an arrangement parallel to the membrane surface, the hydrophobic region is localized about $10 \AA$ above the bilayer centre [58]. This causes the lipid fatty acyl chains to move underneath the helical domain (Figure 3), concomitant with a disordering of the fatty acyl chain packing [106] and membrane thinning [61,107]. Ultimately, the formation of membrane openings [66] and macroscopic phase transitions of the peptide-lipid assembly occur [89] (Figure 4). F4 Solid-state NMR measurements in the presence of magainins and other amphipathic peptides have indeed monitored changes in the order parameter at the lipid bilayer interior that agree with such a model $[106,108]$. The bilayer disruptions extend far beyond the immediate proximity of the membrane-inserted peptides and have been estimated to cover a radius of approximately $50 \AA[109,110]$.

In many ways, the peptide interacts with the lipid membranes in a manner analogous to a detergent [89]. Whereas at high peptide concentrations both peptides and detergents cause the disruption of the bilayer integrity as suggested by the 'carpet model' [111], a variety of supramolecular arrangements can be obtained at lower concentrations [112-114] including 'aggregates' of undefined molecular structure [115]. Therefore, 'detergent-like' should not be confounded with 'always lytic'. In contrary, it should be kept in mind that at lower detergent (peptide) concentrations, these molecules may even result in more stable lipid bilayer arrangement, for example, when the inverted cone-shaped structure of a detergent compensates for the strain imposed by a cone-shaped PE lipid $[108,116,117]$ (Figure 3(B)). Depending on lipid composition, peptide concentration, $\mathrm{pH}$, temperature and other environmental factors, a stochastic and transient rupture and closure of the membrane is possible (Figure 3(C)-(E)), which can explain the electrophysiological traces, which look (only) on first glance like those expected when well-defined channel structures form [62-64].

Recent publications had shown that other important physicochemical properties of the membranes change upon association of AMPs. For example, a recent study showed that the lateral and rotational diffusion of membrane components is reduced in the presence of the AMP alamethcin or the cationinc PMAP-23 sequence (Table 1) [118]. As contacts and exchange between membrane components are essential for proper functioning, this can have detrimental effects on the viability of the cells.

Finally, it should be considered than many peripheral membrane proteins and components associate through electrostatic interactions. With a high density of cationic AMPs [53], screening the negative charges causes the release of many of these proteins, thereby interfering with cell viability [101].

\section{Synergistic Enhancement of the Activities of AMPs}

Interestingly, the efficiency of some antimicrobial compounds is considerably potentiated when applied in combination. Such synergistic enhancements have been observed for naturally occurring 


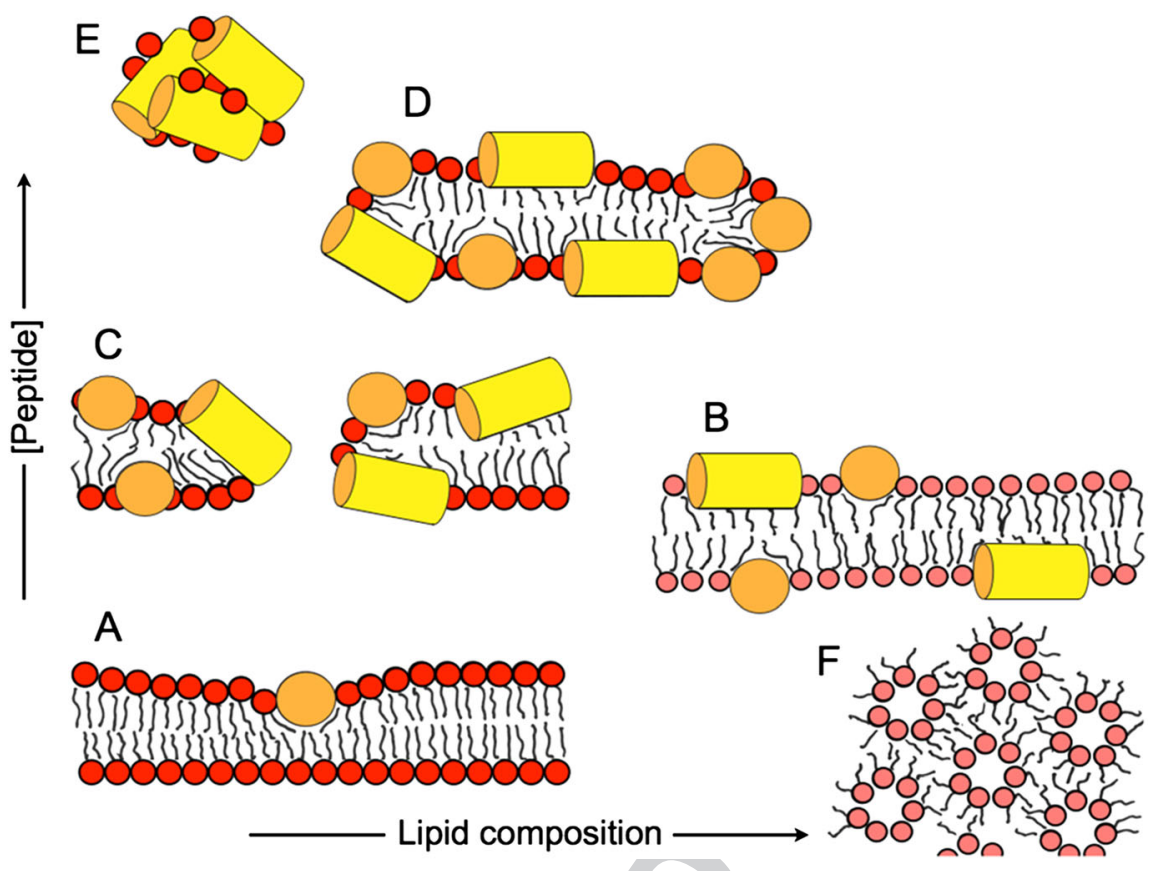

Figure 4. Different structures of peptide-lipid assemblies. Whereas the peptide concentration increases along the $y$-axis, the lipid composition changes from more cylindrical to more cone shaped along the $x$-axis. The different supramolecular assemblies can thus also represent different areas in a phase diagram. (A, B) Bilayers of PC and PE, respectively. (C) Toroidal pore-like arrangement of lipids and peptides. (D) Bicelle emanating from a dense carpet of peptide on a lipid membrane. (E) Micelle at high peptide-to-lipid ratios. (F) The tendency of hexagonal phase formation by cone shaped lipids (such as PE at higher temperatures). To include more hydrophobic sequences into this phase diagram, panel A should be modified by a sketch similar to Figure 1(A).

cocktails of peptide antibiotics such as magainin 2 and PGLa $[119,120]$, but also for mixtures of peptides with conventional antibiotics [121] or ions [122]. When cocktails of peptides have been investigated by solid-state NMR spectroscopy, magainin 2 has been shown to enhance the tendency of PGLa to adopt a tilted/more TM orientation in DMPC or DMPC/DMPG membranes [93]. In contrast, PGLa and magainin 2 are found to both orient parallel to the membrane surface in bilayers made of phospholipids carrying at least one unsaturated fatty acyl chain $[92,123]$. These latter are thought to represent more closely the natural composition of biological membranes, and therefore, an explanation is searched for the synergistic enhancement of magainin 2/PGLa where both of the peptides remain oriented parallel to the surface. On the one hand, synergisms have been found to be specific for certain peptides where the replacements of selected residues has a pronounced effect on synergism [120,124]. On the other hand, neither strong interactions nor a defined interaction surface could be identified so far $[125,126]$. Therefore, the puzzling question why the two peptides in combination are so much more active not only in antimicrobial assays [119] but also calcein release experiments across model membranes remains to be solved [120].

Although at the present time the question how synergism occurs cannot be answered, it is interesting to note that the situation resembles that of the early 1990s where the structural data indicated that cationic amphipathic peptides reside at the membrane interface rather than adopt a TM alignment $[76,77]$. Years of research were needed to accumulate sufficient experimental data to conclusively show that membrane openings and antimicrobial activities can be explained with such in-plane alignments $[53,117,127,128]$. In a related manner, our initial view of synergism to occur by the formation of TM helical bundles made by the ensemble of interacting peptides is in disagreement with biophysical data $[92,123]$, and novel ideas need to be developed. In this context, the SMART model provides a formidable framework to introduce new concepts to also extend for an explanation of the synergistic activities of peptides.

\section{The SMART Model}

Upon membrane insertion, the amphipathic peptides intercalate in between the lipid head groups and thereby act as a spacer at the membrane interface. As a result chain bends, increased transgauche isomerization or chain interdigitation are introduced into the lipid fatty acyl chains [117]. Overall, the response of the lipids should depend on the detailed peptide alignment and penetration depth, which are determined by the charge, hydrophobicity, conformation and the resulting hydrophobic moment and amino acid distribution. However, also the size and shape of the lipid head groups contribute to the overall supramolecular arrangement of the peptide-lipid system. Indeed, it has been observed that the wedge-like properties of the in-plane oriented helices can be partially compensated for by the presence of cone-shaped shaped lipids such as POPE $[108,116]$. Thus, the mode of interaction depends on the peptide sequence, its three-dimensional structure (distribution of hydrophilic and hydrophobic amino acids), the peptide concentration and the physicochemical properties of the membrane (concept reviewed in $[89,117]$ ), which together establish a delicate balance of interactions.

As a consequence, a number of sufficiently different supramolecular arrangements of the peptides and lipids can form (Figure 4). Whereas at lower peptide concentrations stochastic fluctuations of the in-planar peptides within the membrane surface can explain the transient and step-wise enhancements in membrane conductivity that have been observed experimentally (reviewed in [69]; Figure 3), increasing the number of membrane-associated peptides may result in the formation of toroidal pores $[112,113]$, or a 'carpet' of peptides aligned parallel to the surface [111] or structurally badly 
defined peptide aggregates within the membrane [115]. Further increasing the peptide-to-lipid ratios can cause the formation of worm-like structures or disc-shaped particles including bicelles, macrodiscs, nanodiscs and micelles [108,111,115,129].

The lipid membranes are soft and can adapt to a certain degree to the disruptive properties of the peptides, but at higher peptide concentrations, macroscopic phase transitions result, first locally and later upon addition of more peptide globally. Some of the responses may be transient, for example, to allow for the passage of peptides from one bilayer leaflet to the other, which is expected to happen when peptides approach the membrane only from the outside of the bacterium or of the outer monolayer of a vesicle. This extensive plasticity of phospholipid membranes when interacting with peptides is best described by phase diagrams where the large range of supramolecular morphologies are represented as a function of peptide-to-lipid ratio, the detailed membrane composition, temperature, hydration and buffer composition [117] (cf Figure 4). Indeed, transitions between in-plane and TM alignments have been monitored where the membrane topologies of some peptides depend of hydration, $\mathrm{pH}$, peptide-to-lipid ratio and lipid composition [16,130-132] (Figure 1).

In such a phase diagram, conditions exist where bilayers form (Figure $4(A),(B)$ ). These can be stable, slightly perturbed or for some lipid compositions even relieved from inherent curvature strain by the insertion of polypeptide (Figure 4(B)). At higher ratios of membrane-associated peptide-per-lipid phase, transitions occur where membrane disintegration into bicelle-like structures (Figure 4(D)), wormholes (Figure $4(C)$ ) or complete lysis occur (Figure 4(E)). At some intermediate conditions, the bilayers may just be slightly destabilized that with stochastic movements of the peptides along the surface the bilayers open transiently and heal again (Figure (3)). Thus, the resulting phase alterations are transient and restricted to a small area, or at different conditions they can affect the membrane globally.

Previously, we have compared the physicochemical interactions of amphipathic AMPs with membranes to those of detergents $[69,117]$, which has caused some misunderstanding as detergents are often associated with membrane dissolution and lysis. This is indeed one of the many facets of the lipid-detergent phase diagram [117]. However, at small concentrations, detergents can even stabilize membranes when these are made up of lipids representing an inverted cone shape [117]. Therefore, following discussions at the Napoli workshop on AMPs, to which this special issue is dedicated, and the Antimicrobial Peptide Symposium 2014 in Lorient, France, here a more comprehensive descriptor for the interactions of peptides (and other molecules) with phospholipid membranes is proposed: Soft Membranes Adapt and Respond, also Transiently, to external stimuli such as AMPs (SMART model).

Within this model, the more hydrophobic sequences (e.g. peptaibols) tend to adopt more stable TM alignments and on first view seem to follow an altogether different mechanism (Figure 1(A)). However, it should be noted that also in the case of alamethicin, in-planar orientations have been detected [16,34], and the shorter peptaibols when interacting with most except the very thin bilayers (C10 or $\mathrm{C} 12$ ) adopt predominant alignments parallel to the membrane surface. Therefore, concepts of the SMART model (Figure 4) may also apply to these peptides where the panel A would need extension to a more complex image such as the one shown in Figure 1(A). Indeed, a recent study demonstrated that the mode of action of alamethicin and cationic antimicrobial sequences cannot easily be discriminated solely by testing the lipid dependence of pore formation in calcein leakage experiments [133], which would be expected if these sequences interacted with membranes in always the same manner. Furthermore, the leak currents observed in the presence of some of the shorter peptaibols [22] could be taken as an indication of membrane thinning and a less tight packing of the lipid fatty acyl chains in the presence of peptides (Figure 4(A)).

When looking at the consequence of the SMART model, one would predict that other amphipathic molecules can be developed into potent antibacterial compounds. These should be cationic to assure a high concentration at the surface of negatively charged membranes and exhibit a high hydrophobic moment to intercalate into the membrane interface at the level of the phospholipid headgroups. To avoid unspecific interactions and toxicity for healthy eukaryotic cells, differentiation is usually obtained by tuning the overall hydrophobicity to moderate size. Furthermore, the compounds are too short/small to span the lipid membranes to introduce potential mismatch energies that favour the interfacial localization. Indeed, having recognized that the active mechanism of magainins and related peptides is based on a partial interfacial insertion rather than TM helical bundle formation has resulted in the successful production of new antimicrobials made of either short peptide sequences [134-138], peptide mimetics [139-146] or small molecules composed solely of an aromatic ring system, a hydrophobic chain and cationic functional groups [8].

\section{Acknowledgements}

I gratefully acknowledge a great team of co-workers and colleagues that over the years has contributed to this work. I am particularly grateful to Christopher Aisenbrey who carefully cross-checked the peptide sequences and helical wheels provided in this paper using the original literature where available. The financial support by the Agence Nationale de Recherche (TRANSPEP, ProLipln, MembraneDNP, MemPhys, LABEX Chemistry of Complex Systemes), Vaincre la Mucoviscidose (TG 501), the Marie-Curie Research and Training Network 33439 of the European Commission BIOCONTROL, the RTRA International Center for Frontier Research in Chemistry, the University of Strasbourg, and the CNRS is gratefully acknowledged.

\section{References}

1 Chang S, Sievert DM, Hageman JC, Boulton ML, Tenover FC, Downes FP, Shah S, Rudrik JT, Pupp GR, Brown WJ, Cardo D, Fridkin SK, Staphylococcus V-R. Infection with vancomycin-resistant Staphylococcus aureus containing the vanA resistance gene. New Engl. J. Med. 2003; 348: 1342-1347.

2 Boman HG. Peptide antibiotics and their role in innate immunity. Annu. Rev. Immunol. 1995; 13: 61-92.

3 Zasloff M. Antimicrobial peptides of multicellular organisms. Nature 2002; 415: 389-395.

4 Rollins-Smith LA, Doersam JK, Longcore JE, Taylor SK, Shamblin JC, Carey C, Zasloff MA. Antimicrobial peptide defenses against pathogens associated with global amphibian declines. Dev. Comp. Immunol. Biochem. 2002; 26: 63-72.

5 Dohm MT, Kapoor R, Barron AE. Peptoids: bio-inspired polymers as potential pharmaceuticals. Curr. Pharm. Design 2011; 17: 2732-2747.

6 Arnusch CJ, Albada HB, van Vaardegem M, Liskamp RMJ, Sahl HG, Shadkchan Y, Osherov N, Shai Y. Trivalent ultrashort lipopeptides are potent $\mathrm{pH}$ dependent antifungal agents. J. Med. Chem. 2012; 55: 1296-1302.

7 Al-Ahmad A, Laird D, Zou P, Tomakidi P, Steinberg T, Lienkamp K. Nature-inspired antimicrobial polymers - assessment of their potential for biomedical applications. PLoS One 2013; 8: e73812.

8 Ghosh C, Manjunath GB, Akkapeddi P, Yarlagadda V, Hoque J, Uppu DSSM, Konai MM, Haldar J. Small molecular antibacterial peptoid mimics: the simpler the better!. J. Med. Chem. 2014; 57: 1428-1436. 
9 Liu RH, Chen XY, Hayouka Z, Chakraborty S, Falk SP, Weisblum B, Masters KS, Gellman SH. Nylon-3 polymers with selective antifungal activity. J. Am. Chem. Soc. 2013; 135: 5270-5273.

10 Bechinger B. Structure and functions of channel-forming polypeptides: magainins, cecropins, melittin and alamethicin. J. Membr. Biol. 1997; 156: 197-211.

11 Bechinger B. Insights into the mechanisms of action of host defence peptides from biophysical and structural investigations. J. Pept. Sci. 2011; 17: 306-314.

12 Lear JD, Wasserman ZR, DeGrado WF. Synthetic amphiphilic peptide models for protein ion channels. Science 1988; 240: 1177-1181.

13 Killian JA, de Planque MRR, van der Wel PCA, Salemink I, De Kruijff B, Greathouse DV, Koeppe RE. Modulation of membrane structure and function by hydrophobic mismatch between proteins and lipids. Pure Appl. Chem. 1998; 70: 75-82.

14 Harzer $\mathrm{U}$, Bechinger B. The alignment of lysine-anchored membrane peptides under conditions of hydrophobic mismatch: $a C D, 15 \mathrm{~N}$ and 31 P solid-state NMR spectroscopy investigation. Biochemistry 2000; 39: 13106-13114.

15 Hong M, Su Y. Structure and dynamics of cationic membrane peptides and proteins: insights from solid-state NMR. Protein Sci. 2011; 20: 641-655.

16 Salnikov E, Aisenbrey C, Vidovic V, Bechinger B. Solid-state NMR approaches to measure topological equilibria and dynamics of membrane polypeptides. Biochim. Biophys. Acta 2010; 1798: 258-265.

17 Leitgeb B, Szekeres A, Manczinger L, Vagvolgyi C, Kredics L. The history of alamethicin: a review of the most extensively studied peptaibol. Chem. Biodivers. 2007; 4: 1027-1051.

18 Eisenberg M, Hall JE, Mead CA. The nature of the voltage-dependent conductance induced by alamethicin in black lipid membranes. J. Membr. Biol. 1973; 14: 143-176.

19 Boheim G. Statistical analysis of alamethicin channels in black lipid membranes. J. Membr. Biol. 1974; 19: 277-303.

20 Noshiro D, Asami K, Futaki S. Metal-assisted channel stabilization: disposition of a single histidine on the $\mathrm{N}$-terminus of alamethicin yields channels with extraordinarily long lifetimes. Biophys. J. 2010; 98: 1801-1808.

21 Balaram P, Krishna K, Sukumar M, Mellor IR, Sansom MS. The properties of ion channels formed by zervamicins. Eur. Biophys. J. 1992; 21: 117-128.

22 Duclohier $\mathrm{H}$, Snook CF, Wallace BA. Antiamoebin can function as a carrier or as a pore-forming peptaibol. Biochim. Biophys. Acta, Biomembr. 1998; 1415: 255-260.

23 Sansom MS. Alamethicin and related peptaibols-model ion channels. Eur. Biophys. J. 1993; 22: 105-124.

24 Schwarz G, Stankowski S, Rizzo V. Thermodynamic analysis of incorporation and aggregation in a membrane: application to the pore-forming peptide alamethicin. Biochim. Biophys. Acta 1986; 861: 141-151.

25 Sansom MSP. The biophysics of peptide models of lon channels. Prog. Biophys. Mol. Biol. 1991; 55: 139-235.

26 White SH, Wimley WC. Membrane protein folding and stability: physical principles. Annu. Rev. Biophys. Biomol, Struct. 1999; 28: 319-365.

27 Bechinger B. Membrane association and pore formation by alphahelical peptides. Adv. Exp. Med. Biol. 2010; 677: 24-30.

28 Thogersen L, Schiott B, Vosegaard T, Nielsen NC, Tajkhorshid E. Peptide aggregation and pore formation in a lipid bilayer: a combined coarsegrained and all atom molecular dynamics study. Biophys. J. 2008; 95: 4337-4347.

29 North CL, Barranger-Mathys M, Cafiso DS. Membrane orientation of the $\mathrm{N}$-terminal segment of alamethicin determined by solid-state $15 \mathrm{~N}$ NMR. Biophys. J. 1995; 69: 2392-2397.

30 Bak M, Bywater RP, Hohwy M, Thomsen JK, Adelhorst K, Jakobsen HJ, Sorensen OW, Nielsen NC. Conformation of alamethicin in oriented phospholipid bilayers determined by $\mathrm{N}-15$ solid-state nuclear magnetic resonance. Biophys. J. 2001; 81: 1684-1698.

31 Salnikov ES, Friedrich H, Li X, Bertani P, Reissmann S, Hertweck C, O'Neil JD, Raap J, Bechinger B. Structure and alignment of the membrane-associated peptaibols ampullosporin $\mathrm{A}$ and alamethicin by oriented $15 \mathrm{~N}$ and $31 \mathrm{P}$ solid-state NMR spectroscopy. Biophys. J. 2009; 96: 86-100.

32 Yee A, Szymczyna B, O'Neil JD. Backbone dynamics of detergentsolubilized alamethicin from amide hydrogen exchange measurements. Biochemistry 1999; 38: 6489-6498.
33 Jacob J, Duclohier H, Cafiso DS. The role of proline and glycine in determining the backbone flexibility of a channel-forming peptide. Biophys. J. 1999; 76: 1367-1376.

34 Huang HW. Action of antimicrobial peptides: two-state model. Biochemistry 2000; 39: 8347-8352.

35 White SH. http://blanco.biomol.uci.edu/Membrane_Proteins_xtalhtml 2012.

36 Gustavsson M, Verardi R, Mullen DG, Mote KR, Traaseth NJ, Gopinath T, Veglia G. Allosteric regulation of SERCA by phosphorylation-mediated conformational shift of phospholamban. Proc. Natl. Acad. Sci. U. S. A. 2013; 110: 17338-17343.

37 Murray DT, Das N, Cross TA. Solid state NMR strategy for characterizing native membrane protein structures. Acc. Chem. Res. 2013; 46: 2172-2181.

38 Holt A, Killian JA. Orientation and dynamics of transmembrane peptides: the power of simple models. Eur. Biophys. J. Biophy. 2010; 39: 609-621.

39 Zhou HX, Cross TA. Influences of membrane mimetic environments on membrane protein structures. Annu. Rev. Biophys. 2013; 42: 361-392.

40 Wray V, Kinder R, Federau T, Henklein P, Bechinger B, Schubert U. Solution structure and orientation of the transmembrane anchor domain of the HIV-1 encoded virus protein $U$ (Vpu) by highresolution and solid-state NMR spectroscopy. Biochemistry 1999; 38 5272-5282.

41 Aisenbrey C, Cusan M, Lambotte S, Jasperse P, Georgescu J, Harzer U, Bechinger B. Specific isotope labeling of colicin E1 and B channel domains for membrane topological analysis by oriented solid-state NMR spectroscopy. ChemBioChem 2008; 9: 944-951.

42 Aisenbrey C, Sudheendra US, Ridley H, Bertani P, Marquette A, Nedelkina S, Lakey JH, Bechinger B. Helix orientations in membraneassociated $\mathrm{Bcl}-\mathrm{X} \mathrm{L}$ determined by $15 \mathrm{~N}$ solid-state NMR spectroscopy. Eur. Biophys. J. 2007; 36: 451-460.

43 Hall JE, Vodyanoy I, Balasubramanian TM, Marshall GR. Alamethicin: a rich model for channel behavior. Biophys. J. 1984; 45: 233-247.

44 Mouritsen OG, Bloom M. Mattress model of lipid-protein interactions in membranes. Biophys. J. 1984; 46: 141-153.

45 Bobone S, Gerelli Y, De Zotti M, Bocchinfuso G, Farrotti A, Orioni B, Sebastiani F, Latter E, Penfold J, Senesi R, Formaggio F, Palleschi A, Toniolo C, Fragneto G, Stella L. Membrane thickness and the mechanism of action of the short peptaibol trichogin GA IV. Biochim. Biophys. Acta, Biomembr. 2013; 1828: 1013-1024.

46 Bechinger B, Skladnev DA, Ogrel A, Li X, Swischewa NV, Ovchinnikova TV, O'Neil JDJ, Raap J. $15 \mathrm{~N}$ and $31 \mathrm{P}$ solid-state NMR investigations on the orientation of zervamicin II and alamethicin in phosphatidylcholine membranes. Biochemistry 2001; 40: 9428-9437.

47 Bechinger B. Understanding peptide interactions with lipid bilayers: a guide to membrane protein engineering. Curr. Opin. Chem. Biol. 2000; 4: 639-644.

48 Ozdirekcan S, Etchebest C, Killian JA, Fuchs PF. On the orientation of a designed transmembrane peptide: toward the right tilt angle? J. Am. Chem. Soc. 2007; 129: 15174-15181.

49 Esteban-Martin S, Gimenez D, Fuertes G, Salgado J. Orientational landscapes of peptides in membranes: prediction of (2)H NMR couplings in a dynamic context. Biochemistry 2009; 48: 11441-11448.

50 Farrotti A, Bocchinfuso G, Palleschi A, Rosato N, Salnikov ES, Q3 Voievoda N, Bechinger B, Stella L. Molecular dynamics methods to predict peptide location in membranes: LAH4 as a stringent test case. Biochim. Biophys. Acta 2014; in press.

51 Cote S, Binette V, Salnikov ES, Bechinger B, Mousseau N. Probing the dynamics and structure of the huntingtin 1-17 membrane anchor on a phospholipid bilayer using molecular dynamics simulations. submitted 2014.

52 Boman HG. Antibacterial peptides: basic facts and emerging concepts. J. Intern. Med. 2003; 254: 197-215.

53 Roversi D, Luca V, Aureli S, Park Y, Mangoni ML, Stella L. How many AMP molecules kill a bacterium? Spectroscopic determination of PMAP-23 binding to E. coli. Biophys. J. 2014; 106: 292A-A.

54 Diamond G, Beckloff N, Weinberg A, Kisich KO. The roles of antimicrobial peptides in innate host defense. Curr. Pharm. Des. 2009; 15: 2377-2392.

55 Steinstraesser L, Kraneburg U, Jacobsen F, Al-Benna S. Host defense Q6 peptides and their antimicrobial-immunomodulatory duality. Immunobiology 2010.

56 Holzl MA, Hofer J, Steinberger P, Pfistershammer K, Zlabinger GJ. Host antimicrobial proteins as endogenous immunomodulators. Immunol. Lett. 2008; 119: 4-11. 
57 Bechinger B, Zasloff M, Opella SJ. Structure and dynamics of the antibiotic peptide PGLa in membranes by multidimensional solution and solid-state NMR spectroscopy. Biophys. J. 1998; 74: 981-987.

58 Matsuzaki K, Murase O, Tokuda H, Funakoshi S, Fujii N, Miyajima K. Orientational and aggregational states of magainin 2 in phospholipid bilayers. Biochemistry 1994; 33: 3342-3349.

59 Dathe M, Nikolenko H, Meyer J, Beyermann M, Bienert M. Optimization of the antimicrobial activity of magainin peptides by modification of charge. FEBS Lett. 2001; 501: 146-150.

60 Wieprecht T, Apostolov O, Seelig J. Binding of the antibacterial peptide magainin 2 amide to small and large unilamellar vesicles. Biophys. Chem. 2000; 85: 187-198.

61 Ludtke S, He K, Huang H. Membrane thinning caused by magainin 2 . Biochemistry 1995; 34: 16764-16769.

62 Duclohier H, Molle G, Spach G. Antimicrobial peptide magainin I from Xenopus skin forms anion-permeable channels in planar lipid bilayers. Biophys. J. 1989; 56: 1017-1021.

63 Cruciani RA, Barker JL, Zasloff M, Chen HC, Colamonici O. Antibiotic magainins exert cytolytic activity transformed cell lines through channel formation. Proc. Natl. Acad. Sci. U. S. A. 1991; 88: 3792-3796.

64 Christensen B, Fink J, Merrifield RB, Mauzerall D. Channel-forming properties of cecropins and related model compounds incorporated into planar lipid membranes. Proc. Natl. Acad. Sci. U. S. A. 1988; 85: 5072-5076.

65 Islam MZ, Alam JM, Tamba Y, Karal MAS, Yamazaki M. The single GUV method for revealing the functions of antimicrobial, pore-forming toxin, and cell-penetrating peptides or proteins. Phys. Chem. Chem. Phys. 2014; 16: 15752-15767.

66 Gregory SM, Cavenaugh A, Journigan V, Pokorny A, Almeida PFF. A quantitative model for the all-or-none permeabilization of phospholipid vesicles by the antimicrobial peptide cecropin A. Biophys. J. 2008; 94: 1667-1680.

67 Tamba Y, Yamazaki M. Magainin 2-induced pore formation in the lipid membranes depends on its concentration in the membrane interface. J. Phys. Chem. B 2009; 113: 4846-4852.

68 Tamba Y, Ariyama H, Levadny V, Yamazaki M. Kinetic pathway of antimicrobial peptide magainin 2-induced pore formation in lipid membranes. J. Phys. Chem. B 2010; 114: 12018-12026.

69 Bechinger B. The structure, dynamics and orientation of antimicrobial peptides in membranes by multidimensional solid-state NMR spectroscopy. Biochim. Biophys. Acta 1999; 1462: 157-183.

70 Gautier R, Douguet D, Antonny B, Drin G. HELIQUEST: a web server to screen sequences with specific alpha-helical properties. Bioinformatics 2008; 24: 2101-2102.

Q8 71 Gesell J, Zasloff M, Opella SJ. Two-dimensional 1 H NMR experiments show that the 23-residue magainin antibiotic peptide is an a-helix in dodecylphosphocholine micelles, sodium dodecylsulfate micelles, and trifluoroethanol/water solution. J. Biomol. NMR 1997; 127-135.

72 Georgescu J, Verly RM, Bechinger B. NMR structures of the histidine-rich peptide LAH4 in micellar environments: membrane insertion, $\mathrm{pH}$ dependent mode of antimicrobial action and DNA transfection. Biophys. J. 2010; 99: 2507-2515.

73 Holak TA, Engstrom A, Kraulis PJ, Lindeberg G, Bennich H, Jones TA, Gronenborn AM, Clore GM. The solution conformation of the antibacterial peptide cecropin A: a nuclear magnetic resonance and dynamical simulated annealing study. Biochemistry 1988; 27:7620-7629.

74 Wieprecht T, Apostolov O, Beyermann M, Seelig J. Thermodynamics of the alpha-helix-coil transition of amphipathic peptides in a membrane environment: implications for the peptide-membrane binding equilibrium. J. Mol. Biol. 1999; 294: 785-794.

75 Luo P, Baldwin RL. Mechanism of helix induction by trifluoroethanol: a framework for extrapolating the helix-forming properties of peptides from trifluoroethanol/water mixtures back to water. Biochemistry 1997; 36: 8413-8421.

76 Bechinger B, Kim Y, Chirlian LE, Gesell J, Neumann JM, Montal M, Tomich J, Zasloff M, Opella SJ. Orientations of amphipathic helical peptides in membrane bilayers determined by solid-state NMR spectroscopy. J. Biomol. NMR 1991; 1: 167-173.

77 Pouny Y, Rapaport D, Mor A, Nicolas P, Shai Y. Interaction of antimicrobial dermaseptin and its fluorescently labeled analogues with phospholipid membranes. Biochemistry 1992; 31: 12416-12423.

78 Ramamoorthy A, Thennarasu S, Lee DK, Tan A, Maloy L. Solid-state NMR investigation of the membrane-disrupting mechanism of antimicrobial peptides MSI-78 and MSI-594 derived from magainin 2 and melittin. Biophys. J. 2006; 91: 206-216.
79 Strandberg E, Kanithasen N, Tiltak D, Burck J, Wadhwani P, Zwernemann $\mathrm{O}$, Ulrich AS. Solid-state NMR analysis comparing the designer-made antibiotic MSI-103 with its parent peptide PGLa in lipid bilayers. Biochemistry 2008; 47: 2601-2616.

80 Mason AJ, Moussaoui W, Abdelrhaman T, Boukhari A, Bertani P, Marquette A, Shooshtarizaheh P, Moulay G, Boehm N, Guerold B, Sawers RJH, Kichler A, Metz-Boutigue MH, Candolfi E, Prevost G, Bechinger B. Structural determinants of antimicrobial and antiplasmodial activity and selectivity in histidine rich amphipathic cationic peptides. J. Biol. Chem. 2009; 284: 119-133.

81 Fernandez DI, Gehman JD, Separovic F. Membrane interactions of antimicrobial peptides from Australian frogs. Biochim. Biophys. Acta 2009; 1788: 1630-1638.

82 Verly RM, de Moraes CM, Resende JM, Aisenbrey C, Bemquemer MP, Pilo-Veloso D, Valente AP, Alemida FC, Bechinger B. Structure and membrane interactions of the antibiotic peptide dermadistinctin $\mathrm{k}$ by solution and oriented $15 \mathrm{~N}$ and $31 \mathrm{P}$ solid-state NMR spectroscopy. Biophys. J. 2009; 96: 2194-2203.

83 Resende JM, Moraes CM, Munhoz VHDO, Aisenbrey C, Verly RM, Bertani P, Cesar A, Pilo-Veloso D, Bechinger B. Membrane structure and conformational changes of the antibiotic heterodimeric peptide distinctin by solid-state NMR spectroscopy. Proc. Natl. Acad. Sci. U. S. A. 2009; 106: 16639-16644.

84 Bechinger B, Resende JM, Aisenbrey C. The structural and topological Q10 analysis of membrane-associated polypeptides by oriented solid-state NMR spectroscopy: established concepts and novel developments. J. Biophys. Chem. 2010; in press.

85 Resende JM, Verly RM, Aisenbrey C, Amary C, Bertani P, Pilo-Veloso D, Bechinger B. Membrane interactions of Phylloseptin-1, -2, and -3 peptides by oriented solid-state NMR spectroscopy. Biophys. J. 2014; 107: 901-911.

86 Rzepiela AJ, Sengupta D, Goga N, Marrink SJ. Membrane poration by antimicrobial peptides combining atomistic and coarse-grained descriptions. Faraday Discuss. 2010; 144: 431-443.

87 Woo HJ, Wallqvist A. Spontaneous buckling of lipid bilayer and vesicle budding induced by antimicrobial peptide magainin 2: a coarsegrained simulation study. J. Phys. Chem. B 2011; 115: 8122-8129.

88 Israelachvili JN, Marcelja S, Horn RG. Physical principles of membrane organization. Q. Rev. Biophys. 1980; 13: 121-200.

89 Bechinger B. Rationalizing the membrane interactions of cationic amphipathic antimicrobial peptides by their molecular shape. Curr. Opin. Colloid Interface Sci., Surfactants 2009; 14: 349-355.

90 Glaser RW, Sachse C, Durr UH, Wadhwani P, Afonin S, Strandberg E, Ulrich AS. Concentration-dependent realignment of the antimicrobial peptide PGLa in lipid membranes observed by solid-state $19 \mathrm{~F}-\mathrm{NMR}$. Biophys. J. 2005; 88: 3392-3397.

91 Ulmschneider JP, Smith JC, Ulmschneider MB, Ulrich AS, Strandberg E. Reorientation and dimerization of the membrane-bound antimicrobial peptide PGLa from microsecond All-atom MD simulations. Biophys. J. 2012; 103: 472-482.

92 Salnikov E, Bechinger B. Lipid-controlled peptide topology and interactions in bilayers: structural insights into the synergistic enhancement of the antimicrobial activities of PGLa and magainin 2. Biophys. J. 2011; 100: 1473-1480.

93 Tremouilhac P, Strandberg E, Wadhwani P, Ulrich AS. Synergistic transmembrane alignment of the antimicrobial heterodimer PGLa/magainin. J. Biol. Chem. 2006; 281: 32089-32094.

94 Strandberg E, Tiltak D, Ehni S, Wadhwani P, Ulrich AS. Lipid shape is a key factor for membrane interactions of amphipathic helical peptides. Biochim. Biophys. Acta 2012; 1818: 1764-1776.

95 Wieprecht T, Beyermann M, Seelig J. Binding of antibacterial magainin peptides to electrically neutral membranes: thermodynamics and structure. Biochemistry 1999; 38: 10377-10378.

96 Wenk M, Seelig J. Magainin 2 amide interaction with lipid membranes: calorimetric detection of peptide binding and pore formation. Biochemistry 1998; 37: 3909-3916.

97 Bechinger B. Membrane-lytic peptides. Crit. Rev. Plant Sci. 2004; 23: 271-292.

98 Lohner K. New strategies for novel antibiotics: peptides targeting bacterial cell membranes. Gen. Physiol. Biophys. 2009; 28: 105-116.

99 Matsuzaki K, Harada M, Funakoshi S, Fujii N, Miyajima K. Physicochemical determinants for the interactions of magainins 1 and 2 with acidic lipid bilayers. Biochim. Biophys. Acta 1991; 1063: 162-170.

100 Klocek G, Seelig J. Melittin interaction with sulfated cell surface sugars. Biochemistry 2008; 47: 2841-2849. 
101 Wenzel M, Chiriac Al, Otto A, Zweytick D, May C, Schumacher C, Gust R, Albada HB, Penkova M, Kramer U, Erdmann R, Metzler-Nolte N, Straus SK, Bremer E, Becher D, Brotz-Oesterhelt H, Sahl HG, Bandow JE. Small cationic antimicrobial peptides delocalize peripheral membrane proteins. Proc. Natl. Acad. Sci. U. S. A. 2014; 111: E1409-E1418.

Q12 102 Perrone B, Miles AJ, Salnikov ES, Wallace B, Bechinger B. Lipidinteractions of the LAH4, a peptide with antimicrobial and nucleic transfection activities. Eur. Biophys. J. 2014; epub. Sep. 3.

103 Mason AJ, Martinez A, Glaubitz C, Danos O, Kichler A, Bechinger B. The antibiotic and DNA-transfecting peptide LAH4 selectively associates with, and disorders, anionic lipids in mixed membranes. FASEB J. 2006; 20: 320-322.

104 Voievoda N. Biophysical investigations of the membrane and nucleic acids interactions of the transfection peptide LAH4-L1. PhD thesis, University of Strasbourg, 2014.

105 Aisenbrey C, Bechinger B. Molecular packing of amphipathic peptides on the surface of lipid membranes. Langmuir 2014; 30: 10374-10383.

106 Salnikov ES, Mason AJ, Bechinger B. Membrane order perturbation in the presence of antimicrobial peptides by $2 \mathrm{H}$ solid-state NMR spectroscopy. Biochimie 2009; 91: 743.

107 Kim C, Spano J, Park EK, Wi S. Evidence of pores and thinned lipid bilayers induced in oriented lipid membranes interacting with the antimicrobial peptides, magainin-2 and aurein-3.3. Biochim. Biophys. Acta 2009; 1788: 1482-1496.

108 Hallock KJ, Lee DK, Omnaas J, Mosberg HI, Ramamoorthy A. Membrane composition determines pardaxin's mechanism of lipid bilayer disruption. Biophys. J. 2002; 83: 1004-1013.

109 Chen FY, Lee MT, Huang HW. Evidence for membrane thinning effect as the mechanism for peptide-induced pore formation. Biophys. J. 2003; 84: 3751-3758.

110 Mecke A, Lee DK, Ramamoorthy A, Orr BG, Banaszak Holl MM. Membrane thinning due to antimicrobial peptide binding: an atomic force microscopy study of MSI-78 in lipid bilayers. Biophys. J. 2005; 89 : 4043-4050.

111 Shai Y. Mechanism of the binding, insertion, and destabilization of phospholipid bilayer membranes by alpha-helical antimicrobial and cell non-selective lytic peptides. Biochim. Biophys. Acta 1999; 1462 . 55-70.

112 Ludtke SJ, He K, Heller WT, Harroun TA, Yang L, Huang HW. Membrane pores induced by magainin. Biochemistry 1996; 35: 13723-13728.

113 Matsuzaki K. Magainins as paradigm for the mode of action of pore forming polypeptides. Biochim. Biophys. Acta 1998; 1376: 391-400.

114 Rzepiela AJ, Sengupta D, Goga N, Marrink SJ. Membrane poration by antimicrobial peptides combining atomistic and coarse-grained descriptions. Faraday Discuss. 2010; 144: 431-443; discussion 45-81.

115 Jenssen H, Hamill P, Hancock RE. Peptide antimicrobial agents. Clin. Microbiol. Rev. 2006; 19: 491-511.

116 Batenburg AM, van Esch JH, De Kruijff B. Melittin-induced changes of the macroscopic structure of phosphatidylethanolamines. Biochemistry 1988; 27: 2324-2331.

117 Bechinger B, Lohner K. Detergent-like action of linear cationic membrane-active antibiotic peptides. Biochim. Biophys. Acta 2006; 1758: $1529-1539$.

118 Roversi D, Giordano L, De Zotti M, Bocchinfuso G, Farrotti A, Bobone S, Palleschi A, Park Y, Hahm KS, Formaggio F, Toniolo C, Stella L. Membrane-perturbing effects of antimicrobial peptides: a systematic spectroscopic analysis. J. Pept. Sci. 2012; 18: S64-S.

119 Westerhoff HV, Zasloff M, Rosner JL, Hendler RW, de Waal A, Vaz G, Jongsma PM, Riethorst A, Juretic D. Functional synergism of the magainins PGLa and magainin-2 in Escherichia coli, tumor cells and liposomes. Eur. J. Biochem. 1995; 228: 257-264.

120 Matsuzaki K, Mitani Y, Akada K, Murase O, Yoneyama S, Zasloff M, Miyajima K. Mechanism of synergism between antimicrobial peptides magainin 2 and PGLa. Biochemistry 1998; 37: 15144-15153.

121 Bashford CL, Alder GM, Menestrina G, Micklem KJ, Murphy J,, Pasternack JA. Membrane damage by hemolytic viruses,toxins, complement,and other cytotoxic agents. J. Biol. Chem. 1986; 261: 9300-9308.

122 Walkenhorst WF, Sundrud JN, Laviolette JM. Additivity and synergy between an antimicrobial peptide and inhibitory ions. Biochim. Biophys. Acta, Biomembr. 2014; 1838: 2234-2242.
123 Strandberg E, Zerweck J, Wadhwani P, Ulrich AS. Synergistic insertion of antimicrobial magainin-family peptides in membranes depends on the lipid spontaneous curvature. Biophys. J. 2013; 104: L09-L11.

124 Zerweck J, Strandberg E, Wadhwani P, Ulrich AS. Structure activity relationship for a synergistic pair of antimicrobial peptides from the magainin family. Biophys. J. 2014; 106: 294a.

125 Hara T, Mitani Y, Tanaka K, Uematsu N, Takakura A, Tachi T, Kodama H, Kondo M, Mori H, Otaka A, Nobutaka F, Matsuzaki K. Heterodimer formation between the antimicrobial peptides magainin 2 and PGLa in lipid bilayers: a cross-linking study. Biochemistry 2001; 40: 12395-12399.

126 Nishida M, Imura Y, Yamamoto M, Kobayashi S, Yano Y, Matsuzaki K. Interaction of a magainin-PGLa hybrid peptide with membranes: insight into the mechanism of synergism. Biochemistry 2007; 46: 14284-14290.

127 Vogt TCB, Bechinger B. The interactions of histidine-containing amphipathic helical peptide antibiotics with lipid bilayers: the effects of charges and pH. J. Biol. Chem. 1999; 274: 29115-29121.

128 Leontiadou $\mathrm{H}$, Mark AE, Marrink SJ. Antimicrobial peptides in action. J. Am. Chem. Soc. 2006; 128: 12156-12161.

129 Bechinger B. Detergent-like properties of magainin antibiotic peptides: A 31P solid-state NMR study. Biochim. Biophys. Acta 2005; 1712: 101-108.

130 Huang HW, Wu Y. Lipid-alamethicin interactions influence alamethicin orientation. Biophys. J. 1991; 60: 1079-1087.

131 Bechinger B. Towards membrane protein design: $\mathrm{pH}$-sensitive topology of histidine-containing polypeptides. J. Mol. Biol. 1996; 263: 768-775.

132 Huang HW. Molecular mechanism of antimicrobial peptides: the origin of cooperativity. Biochim. Biophys. Acta 2006; 1758: 1292-1302.

133 Bobone S, Roversi D, Giordano L, De Zotti M, Formaggio F, Toniolo C, Park Y, Stella L. The lipid dependence of antimicrobial peptide activity is an unreliable experimental test for different pore models. Biochemistry 2012; 51: 10124-10126.

134 Kindrachuk J, Napper S. Structure-activity relationships of multifunctional host defence peptides. Mini Rev. Med. Chem. 2010; 10 596-614.

135 Liu SP, Zhou L, Lakshminarayanan R, Beuerman RW. Multivalent antimicrobial peptides as therapeutics: design principles and structural diversities. Int. J. Pept. Res. Ther. 2010; 16: 199-213.

136 Hadley EB, Hancock RE. Strategies for the discovery and advancement of novel cationic antimicrobial peptides. Curr. Top. Med. Chem. 2010; 10: 1872-1881.

137 Schweizer F. Cationic amphiphilic peptides with cancer-selective toxicity. Eur. J. Pharmacol. 2009; 625: 190-194.

138 Oyston PC, Fox MA, Richards SJ, Clark GC. Novel peptide therapeutics for treatment of infections. J. Med. Microbiol. 2009; 58: 977-987.

139 Makovitzki A, Baram J, Shai Y. Antimicrobial lipopolypeptides composed of palmitoyl Di- and tricationic peptides: in vitro and in vivo activities, self-assembly to nanostructures, and a plausible mode of action. Biochemistry 2008; 47: 10630-10636.

140 Patch JA, Barron AE. Helical peptoid mimics of magainin-2 amide. J. Am. Chem. Soc. 2003; 125: 12092-12093.

141 Porter EA, Weisblum B, Gellman SH. Mimicry of host-defense peptides by unnatural oligomers: antimicrobial beta-peptides. J. Am. Chem. Soc. 2002; 124: 7324-7330.

142 Kuroda K, DeGrado WF. Amphiphilic polymethacrylate derivatives as antimicrobial agents. J. Am. Chem. Soc. 2005; 127: 4128-4129.

143 Violette A, Fournel S, Lamour K, Chaloin O, Frisch B, Briand JP, Monteil H, Guichard G. Mimicking helical antibacterial peptides with nonpeptidic folding oligomers. Chem. Biol. 2006; 13: 531-538.

144 Palermo EF, Kuroda K. Structural determinants of antimicrobial activity in polymers which mimic host defense peptides. Appl. Microbiol. Biotechnol. 2010; 87: 1605-1615.

145 Scott RW, DeGrado WF, Tew GN. De novo designed synthetic mimics of antimicrobial peptides. Curr. Opin. Biotechnol. 2008; 19: 620-627.

146 Rotem S, Mor A. Antimicrobial peptide mimics for improved therapeutic properties. Biochim. Biophys. Acta 2009; 1788: 1582-1592. 


\section{Review}

The SMART model: Soft Membranes Adapt and Respond, also Transiently, in the presence of antimicrobial peptides

Burkhard Bechinger
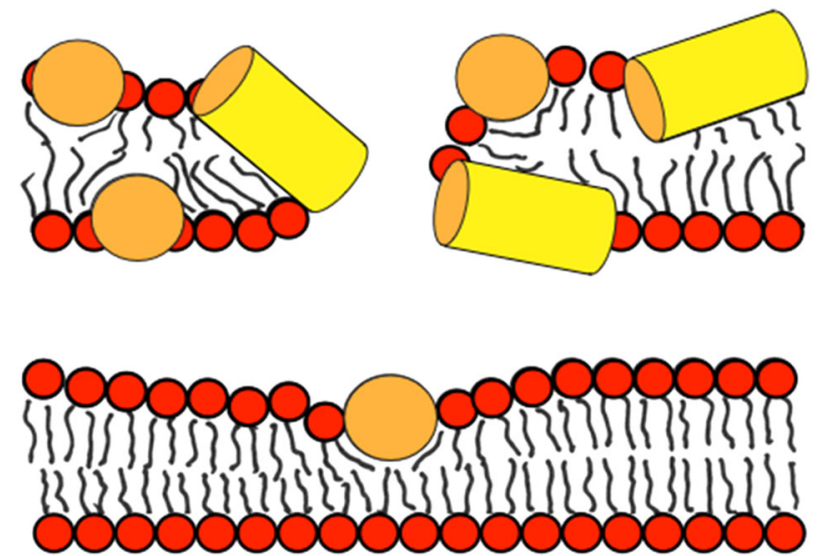

The SMART model aims to provide a unifying view, based on biophysicochemical principles, on how lipids and antimicrobial peptides interact with each other. The resulting supramolecular ensemble shapes on a local, global and transient level the resulting membrane and its biological properties. 


\section{Author Query Form}

\section{Journal: Journal of Peptide Science}

\section{Article: psc_2729}

Dear Author,

During the copyediting of your paper, the following queries arose. Please respond to these by annotating your proofs with the necessary changes/additions.

- If you intend to annotate your proof electronically, please refer to the E-annotation guidelines.

- If you intend to annotate your proof by means of hard-copy mark-up, please refer to the proof mark-up symbols guidelines. If manually writing corrections on your proof and returning it by fax, do not write too close to the edge of the paper. Please remember that illegible mark-ups may delay publication.

Whether you opt for hard-copy or electronic annotation of your proofs, we recommend that you provide additional clarification of answers to queries by entering your answers on the query sheet, in addition to the text mark-up.

\begin{tabular}{|c|l|c|}
\hline Query No. & \multicolumn{1}{|c|}{ Query } & Remark \\
\hline Q1 & $\begin{array}{l}\text { AUTHOR: Reference citations have been renumbered. Please confirm that changes are } \\
\text { correct. }\end{array}$ & \\
\hline Q2 & $\begin{array}{l}\text { AUTHOR: The meaning of this sentence is not clear; please rewrite or confirm that the } \\
\text { sentence is correct. }\end{array}$ & \\
\hline Q3 & AUTHOR: Please provide Volume number, Page information for Ref. [50]. & \\
\hline Q4 & $\begin{array}{l}\text { AUTHOR: If references 50 and 84 have now been published in print, please add relevant } \\
\text { volume/issue/page information. }\end{array}$ & \\
\hline Q5 & AUTHOR: Please update the status of References 51 and 102. & \\
\hline Q6 & AUTHOR: Please provide Volume number, Page information for Ref. [55]. & \\
\hline Q7 & AUTHOR: Please provide the volume and page number for Reference 55. & \\
\hline Q8 & AUTHOR: Please provide Volume number for Ref. [71]. & \\
\hline Q9 & AUTHOR: Please provide the volume number for Reference 71. & \\
\hline Q10 & AUTHOR: Please provide Volume number, Page information for Ref. [84]. & \\
\hline Q11 & AUTHOR: References 86 and 114 are identical. Please check. & \\
\hline Q12 & AUTHOR: Please provide Volume number, Page information for Ref. [102]. & \\
\hline Q13 & AUTHOR: Please check article footnote if captured correctly. & \\
\hline
\end{tabular}


Required software to e-Annotate PDFs: Adobe Acrobat Professional or Adobe Reader (version 7.0 or above). (Note that this document uses screenshots from Adobe Reader $\mathrm{X}$ )

The latest version of Acrobat Reader can be downloaded for free at: http://get.adobe.com/uk/reader/

Once you have Acrobat Reader open on your computer, click on the Comment tab at the right of the toolbar:

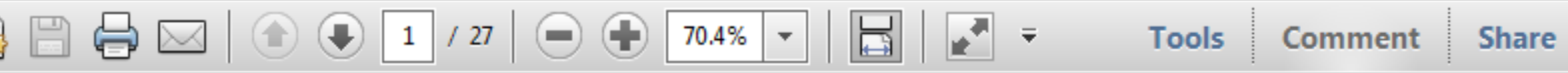

This will open up a panel down the right side of the document. The majority of tools you will use for annotating your proof will be in the Annotations section, pictured opposite. We've picked out some of these tools below:

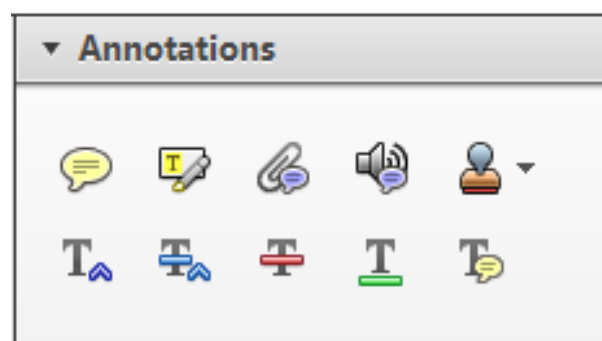

1. Replace (Ins) Tool - for replacing text.

Strikes a line through text and opens up a text box where replacement text can be entered.

How to use it

- Highlight a word or sentence.

- Click on the Replace (Ins) icon in the Annotations section.

- Type the replacement text into the blue box that appears.

Idard tramework for the analysis of $\mathrm{m}$ icy-Nevertheless, it also led to exog،

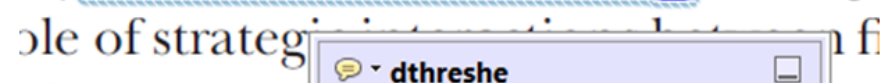
aber of comp 08/06/2011 15:58:17 is that the s1 nain compo: be level, are exc nc

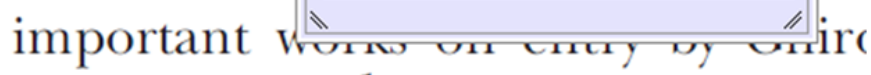
M heneferth) ${ }^{1}$ we anen the "hlarl $\mathrm{l}$

3. Add note to text Tool - for highlighting a section to be changed to bold or italic.

T Highlights text in yellow and opens up a text box where comments can be entered.

\section{How to use it}

- Highlight the relevant section of text.

- Click on the Add note to text icon in the Annotations section.

- Type instruction on what should be changed regarding the text into the yellow box that appears.

namic responses of mark ups ent with the VAR evidence

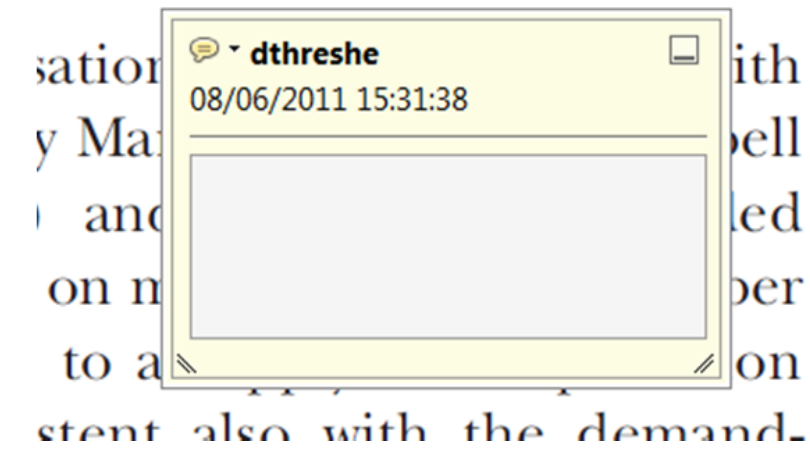

2. Strikethrough (Del) Tool - for deleting text.

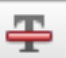

Strikes a red line through text that is to be deleted.

How to use it

- Highlight a word or sentence.

- Click on the Strikethrough (Del) icon in the Annotations section.

there is no room tor extra prohts al c ups are zero and the number of ret) values are not determined by Blanchard and Kiyotaki (1987), sfect competition in general equilil ts of aggregate demand and supply lassical framework assuming monol eph on evorenous number of firme

4. Add sticky note Tool - for making notes at specific points in the text.

Marks a point in the proof where a comment needs to be highlighted.

How to use it

- Click on the Add sticky note icon in the Annotations section.

- Click at the point in the proof where the comment should be inserted.

- Type the comment into the yellow box that appears.

iaisu airu suppiy sirucks. hivsl ui

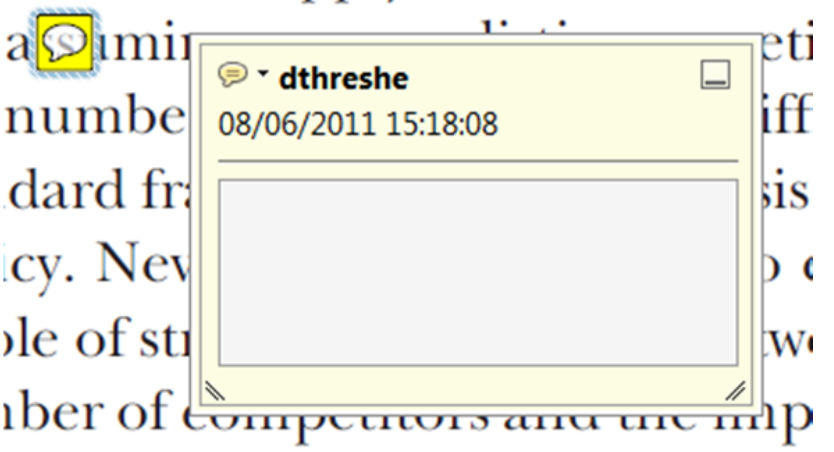

is that the structure of the secto. 
5. Attach File Tool - for inserting large amounts of text or replacement figures.

Inserts an icon linking to the attached file in the appropriate pace in the text.

How to use it

- Click on the Attach File icon in the Annotations section.

- Click on the proof to where you'd like the attached file to be linked.

- Select the file to be attached from your computer or network.

- Select the colour and type of icon that will appear in the proof. Click OK.

E N D

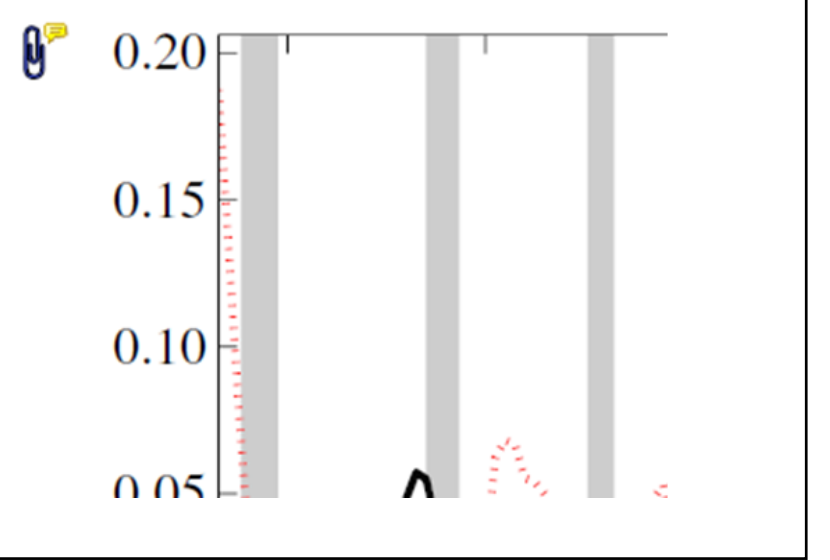

6. Add stamp Tool - for approving a proof if no corrections are required.

- Inserts a selected stamp onto an appropriate place in the proof.

\section{How to use it}

- Click on the Add stamp icon in the Annotations section.

- $\quad$ Select the stamp you want to use. (The Approved stamp is usually available directly in the menu that appears).

- Click on the proof where you'd like the stamp to appear. (Where a proof is to be approved as it is, this would normally be on the first page).

or the business cycie, starting with the on perfect competition, constant ret

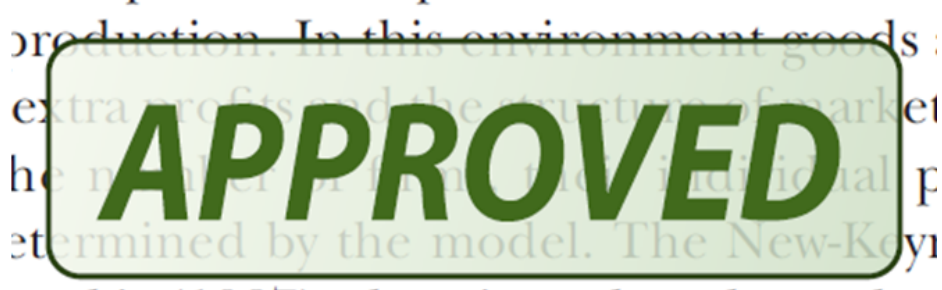
otaki (1987), has introduced produc general equilibrium models with nomin:

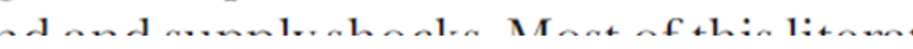

- Drawing Markups

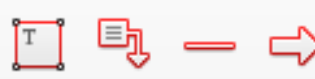

$0 \bigcirc \sqrt{6} \otimes$

\section{How to use it}

- Click on one of the shapes in the Drawing Markups section.

- Click on the proof at the relevant point and draw the selected shape with the cursor.

- To add a comment to the drawn shape, move the cursor over the shape until an arrowhead appears.

- Double click on the shape and type any text in the red box that appears.
7. Drawing Markups Tools - for drawing shapes, lines and freeform annotations on proofs and commenting on these marks.

Allows shapes, lines and freeform annotations to be drawn on proofs and for comment to be made on these marks.

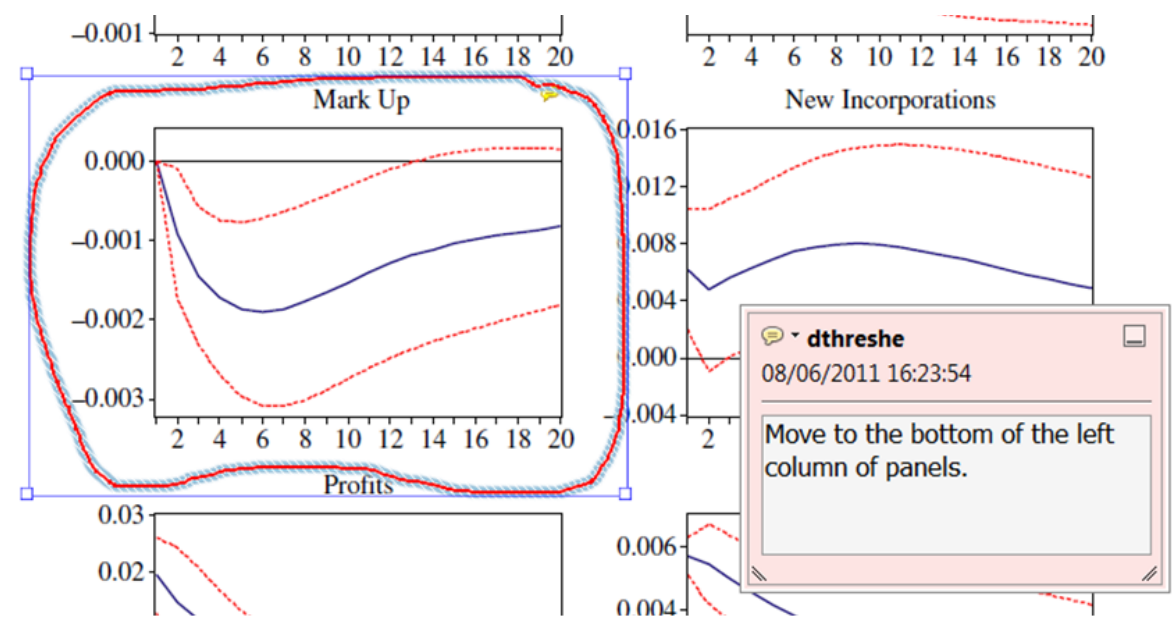

For further information on how to annotate proofs, click on the Help menu to reveal a list of further options:

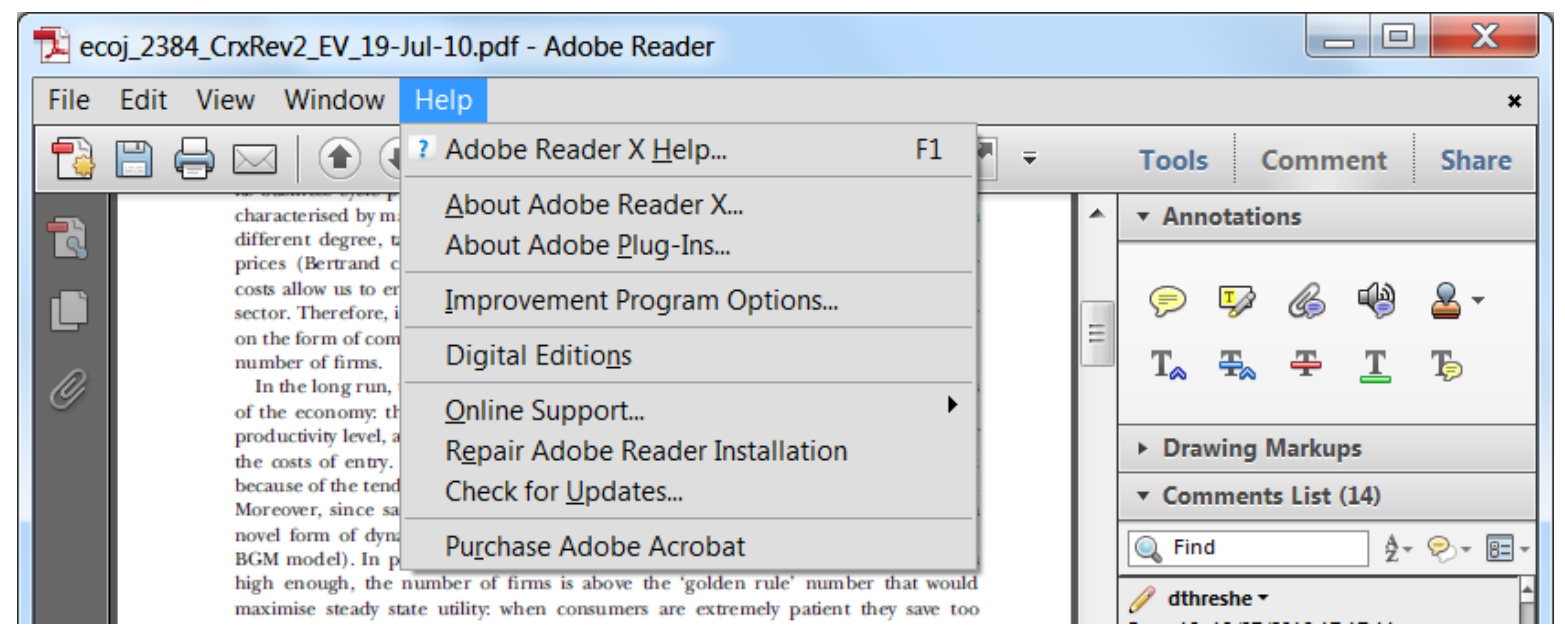

